\title{
PENGARUH ROE DAN DER TERHADAP HARGA SAHAM PERUSAHAAN KERTAS DI BURSA EFEK INDONESIA
}

\author{
Oleh: \\ Mira Munira1 \\ Endang Etty Merawati \\ Shinta Budi Astuti ${ }^{3}$ \\ Dosen Program Studi Akuntansi \\ Fakultas Ekonomi dan Bisnis Universitas Pancasila \\ email: miramunira@univpancasila.ac.id ${ }^{1}$
}

\begin{abstract}
ABSTRAK
Pengaruh Return On Equity (ROE) dan Debt to Equity Ratio (DER) Terhadap Harga Saham Perusahaan Kertas Yang Tercatat Di Bursa Efek Indonesia (BEI). Tujuan penelitian ini adalah untuk mengetahui pengaruh Return on Equity (ROE) dan Debt to Equity Ratio (DER) secara bersamaan dan terpisah terhadap harga saham perusahaan kertas di Bursa Efek Indonesia (BEI). Data yang digunakan dalam penelitian ini adalah data sekunder. Populasi penelitian yaitu tujuh perusahaan pulp \& paper yang tercatat di Bursa Efek Indonesia (BEI) tahun 2012 - 2016 dengan teknik penentuan sampel yang digunakan adalah purposive sampling. Analisis dilakukan dengan teknik analisis deskriptif kuantitatif dengan menggunakan IBM SPSS 21. Hasil analisis data menunjukkan bahwa ROE secara parsial tidak memiliki pengaruh yang berarti terhadap harga saham, DER secara parsial memiliki pengaruh yang berarti terhadap harga saham. Secara bersamaan, ROE dan DER memiliki pengaruh yang berarti terhadap harga saham.
\end{abstract}

Kata kunci : Return On Equity, Debt to Equity, Stock Price

\section{A. PENDAHULUAN}

Dalam era globalisasi dengan ancaman terjadinya krisis ekonomi, tantangan yang harus dihadapi perusahaan menjadi semakin berat, perusaan harus memiliki keunggulan bersaing dibandingkan perusahaan lain agar mampu bertahan dalam industrinya. Apabila perusahaan telah berhasil bertahan dalam segala keadaan perekonomian yang terjadi, dan tetap beroperasi secara efektif dan efisien sehingga kinerja perusahaan dapat dipertahankan atau bahkan meningkat menjadi lebih baik, maka manajemen perusahaan dianggap telah berhasil.

Industri pulp \& paper di Indonesia sangat menarik untuk diteliti. Indonesia memiliki keunggulan kompetitif seperti letak geografisnya, potensi luas izin hutan tanaman industri (HTI) dan kecepatan tumbuh pohon sebagai bahan baku terbarukan. Selain itu, industri pulp \& paper merupakan salah satu industri yang memegang peranan penting dalam perekonomian Indonesia, tidak hanya sebagai penyedia lapangan kerja tetapi juga merupakan salah satu penyumbang devisa yang potensial bagi penerimaan negara dari sektor non migas, terbukti dari 
kontrbusi industri pulp \& paper terhadap devisa negara pada tahun 2015 sebesar 5.3 miliar dollar.

Indonesia memiliki total nilai ekspor produk pulp pada tahun 2011 sebesar 1,544 juta dollar dan produk kertas sebesar 3,544 juta dollar. Industri pulp \& paper Indonesia berkembang cukup baik di pasar dunia, terbukti dari pencapaian Indonesia yang berhasil menduduki peringkat 12 sebagai eksportir kertas pada tahun 2002 dan pada tahun 2011 naik ke peringkat 9. Indonesia bertahan di peringkat 6 sebagai eksportir dunia untuk produk pulp dengan nilai total ekspor pada tahun 2002 sebesar 2.25 juta ton dan sebesar 2.93 juta ton pada tahun 2011 .

Fenomena yang terjadi pada industri manufaktur sub sektor pulp \& paper di Indonesia belakangan ini adalah terjadinya kelesuan ekonomi global yang dimulai tahun 2008, isu lingkungan dan perkembangan teknologi menyebabkan kinerja perusahaan pada sektor industri pulp \& paper tertekan. Tapi pada tahun 2016, beberapa emiten pada sektor industri ini mampu membukukan pertumbuhan pendapatan yang cukup signifikan. Hal tersebut dikarenakan perusahaanperusahaan melakukan diversifikasi produknya sehingga bisa digunakan pada industri consumer goods. Sampai bulan Februari 2017, terdapat enam emiten pada sektor ini mengalami perubahan harga saham. Salah satu emiten, PT.Pabrik Kertas Tjiwi Kimia Tbk. harga sahamnya melonjak 30,14\% dan menyentuh level tertinggi, padahal ditahun 2016 pendapatan perusahaan ini turun sebesar 7,17\%.

Saham merupakan tanda penyertaan modal dalam suatu perusahaan atau perseroan terbatas. Secara sederhana saham juga dapat dikatakan sebagai alat bukti kepemilikan atas sebuah perusahaan. Seseorang/suatu badan yang berinvestasi pada saham memiliki hak atas pendapatan perusahaan, hak atas aset perusahaan dan berhak hadir dalam Rapat Umum Pemegang Saham (RUPS). Bagi perusahaan penerbit saham, saham akan meningkatkan nilai ekuitas perusahaan sehingga perusahaan memiliki struktur modal yang optimal. Selanjutnya perusahaan dapat memanfaatkannya sebagai sarana untuk memperoleh pendanaan. Panji \& Pakarti (2001) mendefinisikan harga saham adalah uang yang dikeluarkan untuk memperoleh bukti penyertaan atau pemilikan suatu perusahaan. Harga saham dapat juga diartikan harga yang dibentuk dari interaksi antara penjual dan pembeli saham yang dilatar belakangi oleh harapan terhadap keuntungan perusahaan.

Salah satu teknik menilai keberhasilan perusahaan adalah melalui analisis terhadap laporan keuangannya. Laporan keuangan adalah laporan pertanggungjawaban manajer atau pimpinan perusahaan atas pengelolaan perusahaan yang dipercayakan kepadanya. Laporan keuangan yang dikeluarkan secara periodik berguna juga untuk mengetahui kinerja suatu perusahaan. Untuk mengetahui kinerja keuangan suatu perusahaan dapat dilakukan dengan menganalisis menggunakan alat-alat analisis keuangan sehingga diperoleh gambaran mengenai baik atau buruknya kondisi keuangan perusahaan pada suatu periode tertentu yang mencerminkan prestasi kerja perusahaan tersebut. Salah satu indikator keberhasilan pengelolaan suatu perusahaan adalah melalui harga sahamnya. Semakin tinggi harga saham suatu perusahaan dapat diartikan semakin baik pengelolaan terhadap perusahaan tersebut. Kondisi yang seperti ini akan menambah kepercayaan para pemodal untuk berinvestasi di perusahaan emiten. 
Berdasarkan latar belakang diatas, maka yang menjadi rumusan masalah pada penelitian ini adalah : (1) adakah pengaruh yang berarti antara ROE dan DER secara bersamaan terhadap harga saham pada perusahaan kertas di BEI, (2) adakah pengaruh yang berarti antara ROE dan DER secara terpisah terhadap harga saham perusahaan kertas di BEI.

Tujuan penelitian ini adalah untuk mengetahui ada atau tidaknya pengaruh yang berarti antara ROE dan DER secara bersamaan terhadap harga saham pada perusahaan kertas di BEI dan untuk mengetahui adakah pengaruh yang berarti antara ROE dan DER secara terpisah terhadap harga saham perusahaan kertas di BEI.

Pembatasan masalah dalam penelitian ini adalah: (1) periode pengamatan selama 5 tahun terakhir yaitu tahun 2012-2016, (2) data yang digunakan adalah ROE dan DER tahun 2012-2016, (3) data 7 perusahaan kertas yang tercatat di BEI.

\section{B. TINJAUAN PUSTAKA}

Kinerja keuangan dapat digambarkan sebagai pengukuran prestasi perusahaan, sebagai hasil keputusan manajemen dalam suatu proses yang kompleks dan sulit karena menyangkut efektivitas penggunaan modal, efisiensi, dan rasio pendapatan kegiatan usaha. Pemahaman mengenai kinerja adalah hasil kerja yang bisa diraih oleh seseorang atau sekelompok orang di suatu perusahaan, berdasarkan kepada kewenangan hukum dan tanggung jawab masing-masing tujuan perusahaan. Berdasarkan uraiannya, dapat disimpulkan bahwa kinerja keuangan perusahaan lebih mencerminkan kondisi perusahaan, yang berasal dari upaya manajemen untuk menentukan kondisi perusahaan dengan menggunakan angka dan pengukuran kinerja spesifik, sehingga menggambarkan kondisi internal perusahaan. Kinerja perusahaan juga menggambarkan kondisi perusahaan bila dibandingkan dengan kondisi eksternal seperti hubungan dengan perusahaan lainnya, hukum, lingkungan, moral, dan etis.

Kinerja keuangan merupakan gambaran umum pencapaian prestasi kerja suatu perusahaan pada suatu periode tertentu yang mendefinisikan kondisi kesehatan keuangan perusahaan dengan indikator likuiditas, profitabilitas, aktivitas dan solvabilitas. Kinerja keuangan diartikan oleh IAI (2007) ialah kemampuan pengelolaan dan pengendalian sumber daya yang dimiliki oleh sebuah perusahaan. Fahmi (2012) berpendapat bahwa analisis yang dilakukan untuk mengetahui apakah aturan-aturan pelaksanaan keuangan pada suatu perusahaan telah dilaksanakan dengan baik dan benar ini dinamakan kinerja keuangan. Dalam menghadapi perubahan lingkungan, perlu adanya optimalisasi penggunaan sumber daya, dan hal ini dapat diketahui melalui kinerja keuangan.

Saham merupakan salah satu efek yang paling diminati oleh investor di bursa efek untuk diperjualbelikan. Saham menunjukkan bagian hak kepemilikan terhadap suatu perusahaan. Darmadji \& Hendy (2006) mengungkapkan bahwa saham merupakan tanda kepemilikan sebuah perusahaan oleh seseorang atau suatu badan. Secara umumnya, harga saham dapat dikatakan harga penutupan yang terbentuk sesuai permintaan dan penawaran yang terjadi pada kegiatan jual-beli di pasar saham. Jogiyanto (2008) mengatakan bahwa harga saham merupakan harga 
suatu saham tertentu pada saat tertentu di pasar bursa yang terbentuk karena adanya interaksi permintaan dan penawaran saham tersebut di pasar modal.

Pergerakan harga saham di pasar bursa dapat dipengaruhi oleh beberapa faktor. Menurut Brigham \& Houston (2010) harga saham suatu perusahaan dipengaruhi oleh beberapa faktor, diantaranya ada faktor internal dan faktor eksternal. Factor internal diantaranya ialah : (1) pemberitahuan iklan dan promosi barang yang akan dijual, (2) pemberitahuan yang berkaitan dengan modal dan hutang, (3) pemberitahuan direksi mengenai struktur organisasi, (4) pemberitahuan mengenai penggabungan investasi yang dilakukan, (5) pemberitahuan mengenai pemberhentian usaha, (6) pemberitahuan informasi yang berkaitan dengan sumber daya manusia, (7) publikasi mengenai laporan keuangan perusahaan. Sementara yang menjadi faktor eksternal yaitu : (1) adanya kebijakan baru dari pemerintah mengenai tingkat inflasi, tingkat suku bunga, dan berbagai regulasi lainnya, (2) pemberitahuan mengenai kasus-kasus hukum yang sedang terjadi di perusahaan, (3) pemberitahuan industry sekuritas.

Harga saham suatu perusahaan juga dapat dipengaruhi oleh kondisi perusahaan atau kinerja perusahaan tersebut. Semakin baik kinerja kinerja perusahaan maka akan semakin meningkatkan laba perusahaan tersebut, dan kemudian akan meningkatkan pulangan untuk investor, sehingga terjadi kenaikan harga saham. Salah satu alat pengukuran kinerja keuangan suatu perusahaan melalui analisis rasio keuangan atas laporan keuangan pada periode tertentu yang telah disediakan oleh manajer. Analisis rasio keuangan dilakukan dengan menggunakan beberapa rasio-rasio keuangan untuk penilaian kinerja pada suatu periode. Rasio-rasio yang umumnya digunakan adalah rasio likuiditas, rasio profitabilitas, rasio aktivitas, dan rasio solvabilitas.

Studi empiris yang dilakukan oleh Ranne Hadiyatika Ramfineli \& Ibrahim (2016) menemukan bahwa secara parsial tidak terdapat pengaruh yang berarti antara GPM, ROI, ROE, EPS terhadap harga saham. Hasil kajian Gere (2015) menyatakan bahwa secara simultan harga saham suatu perusahaan dipengaruhi oleh EPS, ROE, PER dan DER, secara parsial harga saham dipengaruhi signifikan oleh EPS dan PER namun tidak dengan ROE dan DER. Suatu kajian kuantitatif yang dilakukan oleh Aditya (2014) memberikan hasil bahwa secara simultan harga saham perusahaan rokok dipengaruhi signifikan oleh ROA, EPS dan PER, namun secara parsial harga saham perusahaan rokok tidak dipengatuhi signifikan oleh ROA dan EPS serta PER mempengaruhi harga saham secara signifikan.

Satria \& Hatta (2015) melakukan studi empiris dengan hasil yang menyatakan bahwa secara parsial LDR, CAR dan ROE memiliki pengaruh yang berarti terhadap harga saham namun NPL tidak memiliki pengaruh yang berarti terhadap harga saham, sementara secara simultan LDR, CAR, ROE dan NPL memberikan pengaruh yang berarti terhadap harga saham. Penelitian kuantitatif yang dilakukan oleh Zuliarni (2012) memberikan hasil bahwa secara parsial harga saham perusahaan dipengaruhi signifikan oleh ROA dan PER namun DPR tidak memberikan pengaruh yang berarti terhadap harga saham. Penelitian Putri (2017) memberikan hasil uji regresi linear bahwa profitabilitas dan keputusan investasi baik secara parsial maupun secara simultan tidak berpengaruh signifikan terhadap nilai perusahaan, 


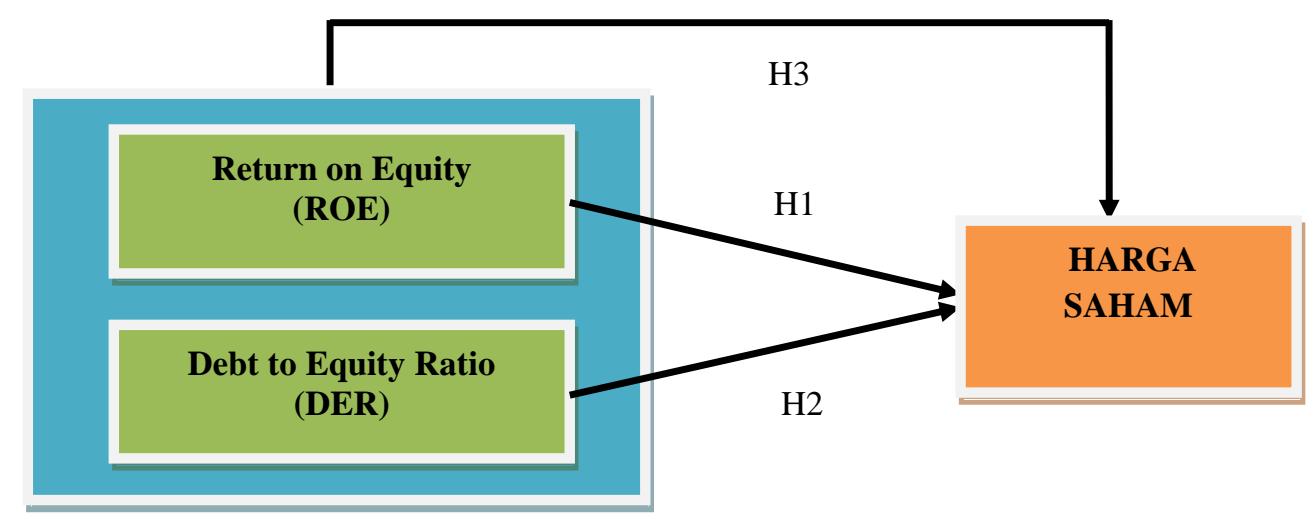

Berdasarkan pada rumusan masalah, tujuan kajian, serta tinjauan teori yang telah diuraikan sebelumnya, maka hipotesis yang dapat diajukan adalah :

H1 : ROE memiliki pengaruh yang berarti terhadap harga saham

H2 : DER memiliki pengaruh yang berarti terhadap harga saham

H3 : ROE dan DER secara bersamaan memberikan pengaruh berarti pada harga saham

\section{METODE PENELITIAN}

Dalam penelitian ini teknik analisis yang digunakan adalah teknik analisis deskriptif, artinya data mengenai permasalahan yang dikaji adalah data yang sistematik, faktual, dan tepat (Sugiyono:2013). Menurut Sugiyono (2010) populasi adalah suatu wilayah yang telah ditetapkan oleh peneliti untuk dipelajari dan ditarik kesimpulannya dimana objek atau subjeknya memiliki kualitas dan karakteristik tertentu. Wilayah penelitian yang digunakan ialah perusahaan pulp \& kertas yang terdaftar di Bursa Efek Indonesia (BEI) tahun 2012 - 2016. Menurut Indriantoro dan Supomo (2002), sampel adalah sebagian dari elemen-elemen populasi, yang mempunyai ciri dan karakteristik yang sama dengan populasi. Cara pengambilan sampel yang digunakan adalah purposive sampling.

Menurut Notoadmodja (2010) metode puporsive sampling adalah metode pengambilan sampel yang berdasarkan atas suatu pertimbangan tertentu seperti sifat-sifat populasi ataupun cirri-ciri yang sudah diketahui sebelumnya. Pengambilan sampel berdasarkan criteria-kriteria berikut ini :

a. Perusahaan kertas yang terdaftar di Bursa Efek Indonesia tahun 2012 sampai dengan 2016.

b. Perusahaan tidak keluar (delisting) dari Bursa Efek Indonesia selama tahun 2012-2016

c. Laporan keuangan disajikan dalam mata uang rupiah dan berakhir pada tanggal 31 Desember dan telah diperiksa oleh auditor independen dari tahun 2012 2016.

Jenis data yang digunakan untuk penelitian ini ialah data sekunder yang didapat dengan mengakses laman www.idx.co.id. Teknik pengumpulan data yang 
digunakan ialah dokumentasi, data dari laporan keuangan yang tersedia di Bursa Efek Indonesia selama periode 2012-2016.

Berdasarkan permasalahan dan hipotesis yang telah dikemukakan sebelumnya, maka terdapat dua variabel yang dianalisis yaitu variabel bebas (independent variabel) dan variabel terikat (dependent variabel). Variabel bebas terdiri dari return on equity (ROE) dan debt to equity ratio (DER). Sedangkan variabel terikat dalam analisis ini adalah harga saham.

Definisi operasional variabel yang digunakan dalam penelitian ini adalah :

\section{Return On Equity (ROE)}

Menurut Agnes (2005), dalam menilai kinerja sebuah perusahaan dapat menggunakan rasio ROE.

Kenaikan ROE biasanya diikuti oleh kenaikan harga saham perusahaan tersebut. ROE yang tinggi dapat menjadi tanda bahwa modal suatu perusahaan telah dikelola dengan baik sehingga mendatangkan keuntungan bagi pemeegang sahamnya, dan ini artinya kinerja perusahaan juga semakin baik.

2. Debt to Equity Ratio (DER)

DER merupakan salah satu rasio leverage atau solvabilitas menurut pandangan Darsono dan Ashari (2010). Rasio solvabilitas ialah rasio yang digunakan untuk mengukur seberapa mampu suatu perusahaan melunasi kewajibannya apabila perusahaan tersebut dilikuidasi. Solvabilitas juga dikenal dengan sebagai rasio pengungkit (leverage) untuk menilai batasan dalam meminjam uang bagi suatu perusahaan.

3. Harga Saham, menurut Agus (2008), harga saham dibentuk dengan adanya transaksi permintaan dan penawaran di pasar bursa. Naiknya harga saham terjadi jika adanya permintaan yang berlebih atas saham tersebut. Sebaliknya, jika penawaran terhadap saham yang berlebih maka harga saham cenderung turun.

Penelitian ini menggunakan teknik analisis deskriptif, dan dalam melakukan analisis data digunakan program IBM SPSS (Statistikal Product and Service Solution) 21 untuk windows. Teknik analisis data yang digunakan adalah :

Uji Hipotesis

a. Uji F

Uji F atau uji serentak atau uji model/uji anova dilakukan untuk mengetahui apakah semua variabel bebas memiliki hubungan signifikan yang sama terhadap variabel terikat. Jika nilai $F_{\text {signifikan }}<0.05$ maka model dapat dikatakan layak digunakan, namun jika nilai $F_{\text {signifikan }}>0.05$ maka model dapat dikatakan tidak layak.

b. Uji t

Dilakukan untuk mengetahui seberapa besar pengaruh variabel independen secara parsial terhadap variabel dependen. Bila (P-Value) $<0.05$, variabel independen secara parsial mempengaruhi variabel dependen. Bila (P-Value) $>$ 0.05 , variabel independen secara parsial tidak mempengaruhi variabel dependen.

c. Uji Asumsi Klasik

1. Uji Normalitas 
Uji normalitas memiliki tujuan agar diketahui apakah data berdistribusi secara normal Erlina (2008). Dalam melakukan uji t dan uji F diasumsikan nilai residual mengikuti distribusi normal. Menurut Ghozali (2006), analisis grafik dan statistik digunakan untuk mendeteksi apakah residual berdistribusi normal atau tidak. Uji normalitas dalam penelitian ini dilakukan dengan pendekatan statistik dengan menggunakan uji statistik Kolmogorov Smirnov (K-S). Pedoman pengambilan keputusan rentang data tersebut mendekati distribusi normal atau telah berdistribusi normal berdasarkan uji Kolmogorov Smirnov dapat diketahui dari : nilai sig. $<0.05$ distribusi data tidak normal; nilai sig >0.05 distribusi data normal.

2. Uji Multikoliniaritas

Ada atau tidaknya korelasi diantara variabel bebas dapat diketahui dengan melakukan uji multikoliniaritas. Jika terjadi korelasi, berarti terjadi masalah multikoliniaritas (Ghozali, 2006). Jika nilai tolerance $<0.10$ dan VIF (Variance Inflation Factor) $>10$ maka terjadi multikoliniaritas. Jika nilai tolerance $>0.10$ dan VIF (Variance Inflation Factor) $<10$ maka tidak terjadi multikoliniaritas.

3. Uji Autokorelasi

Uji autokorelasi digunakan untuk menguji apakah dalam sebuah model regresi linear terdapat korelasi atau hubungan antara kesalahan pengganggu pada periode $t$ dengan kesalahan pengganggu pada periode $t-$ 1 (sebelumnya). Model regresi yang baik seharusnya bebas dari autokorelasi. Deteksi adanya autokorelasi dapat dilakukan dengan dua cara, pertama dengan menggunakan uji Durbin-Watson (Durbin-Watson test) yaitu dengan mengamati nilai D-W statistik hasil perhitungan SPSS, dan kedua melalui uji Run Test yang dilakukan dengan menggunakan program SPSS. Dasar penentuan keputusan pada uji run test : Jika nilai Asymp. Sig. (2-tailed) $<0.05$ maka terdapat gejala autokorelasi. Jika nilai Asymp. Sig. (2-tailed) $>0.05$ tidak ada gejala autokorelasi.

4. Uji Heteroskedastisitas

Pendapat Erlina (2008) mengungkapkan bahwa tujuan dari uji heteroskedastisitas adalah untuk mengetahui apabila ada ketidaksamaan residual variabel antar pengamatan. Model regresi yang baik adalah tidak terjadi heteroskedastisitas (homoskedastisitas). Untuk melihat ada tidaknya heteroskedastisitas pada penelitian ini dengan melakukan Glejser SPSS dengan dasar pengambilan keputusan pada uji heteroskedastisitas menggunakan Glejser SPSS ini adalah :

a) Jika nilai signifikansi $>0.05$ maka tidak terjadi heteroskedastisitas

b) Jika nilai signifikansi $<0.05$ maka terjadi heteroskedastisitas

5. Analisis Linear Berganda

Analisis linear berganda dipilih karena penelitian ini menggunakan variabel bebas lebih dari satu, dimana analisis ini ditujukan untuk mengetahui pengaruh antara variabel bebas terhadap variabel terikat. 
Persamaan regresi linear berganda dapat dilihat dengan rumus sebagai berikut :

$$
Y=a+b 1 R O E+b 2 D E R+e
$$

Dimana :

Y : Harga Saham

a : Konstanta

b1-b2 : Koefisien regresi variabel bebas

ROE : Return on Equity

DER : Debt to Equity Ratio

e : Error (pengganggu)

\section{HASIL DAN PEMBAHASAN}

\section{Pengujian Normalitas Data}

Data yang baik untuk penelitian adalah data yang berdistribusi normal. Alat uji yang dapat digunakan untuk mengetahui bahwa variabel-variabel yang akan di regresi mempunyai distribusi normal atau tidak adalah dengan uji hipotesis. Untuk mengetahui apakah data tersebut berdistribusi normal, dapat diuji dengan metode Kolmogorov Smirnov. Jika probabilitas $>0.05$ maka data tersebut berdistribusi normal dan sebaliknya. Berdasarkan hasil uji normalitas dengan menggunakan program komputer SPSS dapat dilihat pada tabel berikut ini :

Tabel 1

Uji Normalitas Data

One-Sample Kolmogorov-Smirnov Test

\begin{tabular}{|ll|r|}
\hline & & Standardized Residual \\
\hline $\mathrm{N}$ & & 35 \\
Normal Parameters $^{\mathrm{a}, \mathrm{b}}$ & Mean & .0000000 \\
& Std. Deviation & .97014250 \\
& Absolute & .145 \\
Most Extreme Differences & Positive & .145 \\
& Negative & -.091 \\
Kolmogorov-Smirnov Z & & .855 \\
Asymp. Sig. (2-tailed) & & .458 \\
\hline
\end{tabular}

a. Test distribution is Normal.

b. Calculated from data.

Sumber : Data Sekunder Diolah, 2017

Berdasarkan pada tabel diatas dapat diketahui bahwa besarnya nilai Asymp sig (2-tailed) sebesar $0.458>0.050$ sesuai dengan ketentuan yang telah ditetapkan, maka dapat disimpulkan bahwa data tersebut telah berdistribusi normal sehingga layak untuk digunakan dalam penelitian.

\section{Pengujian Multikolinearitas}

Model regresi yang baik seharusnya tidak terjadi korelasi antara variabelvariabel bebas. Uji multikolinearitas digunakan untuk menguji apakah dalam 
persamaan regresi terdapat korelasi antara variabel-variabel bebas. Adanya multikolinearitas dapat diketahui dengan besarnya nilai variance inflation factor (VIF) dimana VIF > 10. Berdasarkan hasil uji multikolinearitas menggunakan program SPSS, diperoleh hasil seperti tabel dibawah ini :

Tabel 2

Nilai Variance Inflation Factor dan Nilai Tolerance

\begin{tabular}{lccl}
\hline Variabel & Tolerance & VIF & Keterangan \\
\hline Return on Equity & 0.995 & 1.005 & Bebas Multikolinieritas \\
\hline Debt to Equity Ratio & 0.995 & 1.005 & Bebas Multikolinieritas \\
\hline
\end{tabular}

Sumber : Data Sekunder Diolah, 2017

Berdasarkan tabel diatas, dapat dilihat bahwa semua variabel bebas yang terdiri dari return on equity dan debt to equity ratio semuanya memiliki nilai tolerance yang lebih besar dari 0.10 dan VIF yang kurang dari 10. Sehingga dapat dinyatakan bahwa seluruh variabel bebas tidak memiliki keterikatan atau hubungan sangat kuat satu sama lain, sehingga dapat disimpulkan model penelitian tidak terjadi gangguan multikolinearitas.

\section{Pengujian Autokorelasi}

Suatu model regresi linear yang baik adalah yang tidak terjadi autokorelasi didalamnya. Pengujian autokorelasi pada penelitian ini dengan menggunakan Uji Run Test yang dilakukan melalui program SPSS. Tabel berikut ini akan menunjukkan hasil pengujian autokorelasi yang telah dilakukan.

Tabel 3

Uji Autokorelasi

Runs Test

\begin{tabular}{|l|r|}
\hline & \multicolumn{1}{|c|}{ Unstandardized Residual } \\
\hline Test Value & -46.11710 \\
Cases < Test Value & 17 \\
Cases >= Test Value & 18 \\
Total Cases & 35 \\
Number of Runs & 13 \\
Z & -1.712 \\
Asymp. Sig. (2-tailed) & .087 \\
\hline
\end{tabular}

a. Median

Sumber : Data Sekunder Diolah, 2017

Dari tabel diatas, diperoleh nilai Asymp. Sig. (2-tailed) adalah sebesar 0.087. hasil pengujian autokorelasi tersebut menunjukkan angka yang lebih besar dari 0.05 , yakni 0.087 , maka dapat disimpulkan bahwa dalam model regresi linear yang digunakan tidak terdapat gejala autokorelasi.

\section{Pengujian Heteroskedatisitas}

Masalah heteroskedastisitas harus dihindari dari suatu model regresi linear yang baik. Untuk mengetahui apakah terjadi heteroskedastisitas atau tidak pada 
model regresi tersebut, maka dalam penelitian ini diuji dengan Glejser SPSS. Hasil pengujian heteroskedastisitas dapat dilihat pada tabel dibawah ini.

Tabel 4

Uji Heteroskedastisitas

Coefficients $^{\text {a }}$

\begin{tabular}{|c|c|c|c|c|c|c|c|c|}
\hline \multirow{2}{*}{\multicolumn{2}{|c|}{ Model }} & \multicolumn{2}{|c|}{$\begin{array}{c}\text { Unstandardized } \\
\text { Coefficients }\end{array}$} & \multirow{2}{*}{$\begin{array}{c}\begin{array}{c}\text { Standardized } \\
\text { Coefficients }\end{array} \\
\text { Beta } \\
\end{array}$} & \multirow[t]{2}{*}{$\mathrm{t}$} & \multirow[t]{2}{*}{ Sig. } & \multicolumn{2}{|c|}{$\begin{array}{c}\text { Collinearity } \\
\text { Statistiks }\end{array}$} \\
\hline & & $\mathrm{B}$ & Std. Error & & & & Tol & VIF \\
\hline \multirow{3}{*}{1} & (Const) & 275.272 & 226.880 & & 1.213 & .234 & & \\
\hline & DER & 141.611 & 138.710 & .177 & 1.021 & .315 & .995 & 1.005 \\
\hline & ROE & 6.908 & 8.938 & .134 & .773 & .445 & .995 & 1.005 \\
\hline
\end{tabular}

a. Dependent Variabel: RES2

Sumber : Data Sekunder Diolah, 2017

Dari hasil pengujian heteroskedastisitas dengan menggunakan Glejser Test diatas, diperoleh nilai signifikansi adalah sebesar 0.445 , berarti lebih besar dari 0.05 yang disyaratkan. Maka dapat disimpulkan bahwa dalam model regresi tidak terjadi heteroskedastisitas.

\section{Uji Hipotesis}

Uji hipotesis merupakan salah satu cabang ilmu statistika inferensial yang digunakan untuk menguji kebenaran suatu pernyataan secara statistik dan menarik kesimpulan apakah menerima atau menolak pernyataan tersebut. Pernyataan atau asumsi sementara yang dibuat dalam penelitian disebut hipotesis. Uji hipotesis bertujuan untuk menetapkan suatu dasar sehingga dapat mengumpulkan bukti yang berupa data-data dalam menentukan keputusan menolak atau menerima kebenaran dari pernyataan yang telah dibuat. Uji hipotesis yang akan dilakukan adalah uji $\mathrm{F}$ dan uji t.

Uji F dilakukan untuk mengetahui adakah hubungan atau pengaruh secara simultan dari variabel-variabel bebas atau independen terhadap variabel terikat atau dependen. Tabel dibawah ini akan menyajikan analisis varians hubungan secara simultan.

Tabel 5

Hasil Analisis Pengaruh Secara Simultan

ANOVA ${ }^{a}$

\begin{tabular}{|c|c|c|c|c|c|c|}
\hline & Model & Sum of Squares & $\mathrm{df}$ & Mean Square & $\mathrm{F}$ & Sig. \\
\hline \multirow{3}{*}{1} & Regression & 8447599.355 & 2 & \multirow{3}{*}{$\begin{array}{r}4223799.678 \\
545287.979\end{array}$} & \multirow[t]{3}{*}{7.746} & \multirow[t]{3}{*}{$.002^{\mathrm{b}}$} \\
\hline & Residual & 17449215.331 & 32 & & & \\
\hline & Total & 25896814.686 & 34 & & & \\
\hline
\end{tabular}

a. Dependent Variabel: HARGA

b. Predictors: (Constant), ROE, DER

Sumber : Data Sekunder Diolah, 2017 
Berdasarkan hasil perhitungan menggunakan SPSS, diperoleh nilai tingkat signifikan sebesar 0.002 dimana tingkat signifikan kurang dari level $\alpha=0.05$ yang artinya variabel ROE dan DER secara bersama-sama mempunyai pengaruh yang berarti terhadap harga saham atau layak diterima.

Uji t dilakukan untuk mengetahui pengaruh masing-masing variabel bebas secara parsial atau individu terhadap variabel terikat. Tabel-tabel dibawah ini akan menyajikan analisis varians hubungan secara parsial.

Tabel 6

Hasil Analisis Pengaruh ROE Secara Parsial ROE Terhadap Harga Saham Coefficients $^{\mathrm{a}}$

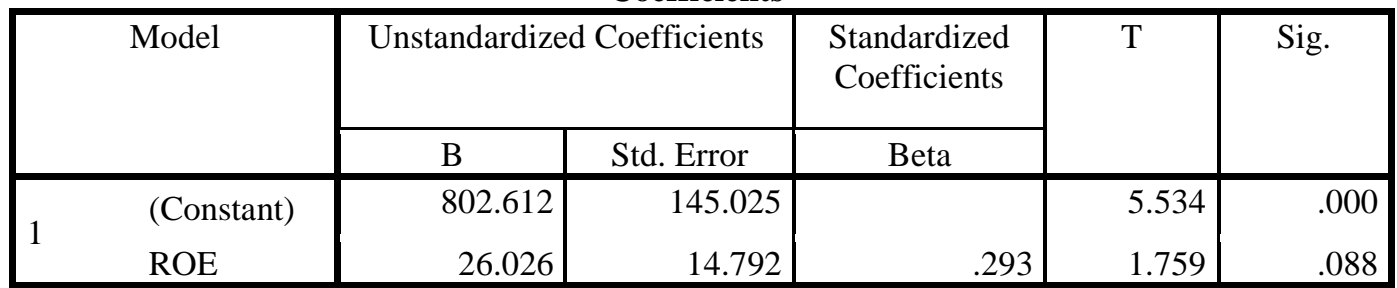

a. Dependent Variabel: HARGA

Sumber : Data Sekunder Diolah, 2017

Dari tabel diatas, dapat diketahui perhitungan ROE dengan menggunakan SPSS bahwa nilai tingkat signifikan sebesar 0.088 yang berarti bahwa tingkat signifikan lebih besar dari level $\alpha=0.05$ maka diperoleh kesimpulan bahwa variabel return on equity secara parsial tidak berpengaruh besar terhadap harga saham, sehingga hipotesis yang diajukan tidak teruji kebenarannya.

Tabel 7

Hasil Analisis Pengaruh DER Secara Parsial DER Terhadap Harga Saham Coefficients $^{\mathrm{a}}$

\begin{tabular}{|c|c|c|c|c|c|c|}
\hline \multirow{2}{*}{\multicolumn{2}{|c|}{ Model }} & \multicolumn{2}{|c|}{ Unstandardized Coefficients } & \multirow{2}{*}{$\begin{array}{c}\text { Standardized } \\
\text { Coefficients }\end{array}$} & \multirow[t]{2}{*}{$\mathrm{t}$} & \multirow[t]{2}{*}{ Sig. } \\
\hline & & $\mathrm{B}$ & Std. Error & & & \\
\hline & (Constant) & -127.494 & 345.013 & & -.370 & .714 \\
\hline & DER & 646.183 & 212.106 & .469 & 3.047 & .005 \\
\hline
\end{tabular}

a. Dependent Variabel: HARGA

Sumber : Data Sekunder Diolah, 2017

Dari tabel diatas, dapat diketahui perhitungan DER dengan menggunakan SPSS bahwa nilai tingkat signifikan sebesar 0.005 yang berarti bahwa tingkat signifikan lebih kecil dari level $\alpha=0.05$ maka diperoleh kesimpulan bahwa variabel debt to equity ratio secara parsial berpengaruh besar terhadap harga saham, sehingga hipotesis yang diajukan teruji kebenarannya. 


\section{Analisis Regresi Linear Berganda}

Analisis regresi linear berganda digunakan untuk mengetahui besarnya pengaruh variabel return on equity (ROE) dan debt to equity ratio (DER) terhadap harga saham perusahaan pulp \& paper yang terdaftar di Bursa Efek Indonesia. Tabel berikut ini menunjukkan hasil perhitungan dengan menggunakan program komputer SPSS :

Tabel 8

Analisis Regresi Linier Berganda

\begin{tabular}{|r|l|r|r|r|r|}
\hline \multirow{2}{*}{ No } & \multirow{2}{*}{ Variabel } & \multirow{2}{*}{ Koefisien Regresi } & \multirow{2}{*}{ Std. Error } & \multicolumn{2}{|c|}{ Korelasi Prasial } \\
\cline { 5 - 6 } & & & \multicolumn{1}{c|}{ t } & \multicolumn{1}{c|}{ Sig. } \\
\hline 1 & Konstanta & -220.681 & 328.157 & -0.672 & 0.506 \\
\hline 2 & DER & 677.962 & 200.629 & 3.379 & 0.002 \\
\hline 3 & ROE & 29.1 & 12.928 & 2.251 & 0.031 \\
\hline
\end{tabular}

Sumber : Data Sekunder Diolah, 2017

Berdasarkan tabel diatas, diperoleh persamaan regresi linear berganda sebagai berikut :

$\mathrm{Y}=-220.681+677.962 \mathrm{DER}+29.1 \mathrm{ROE}$

Dari persamaan tersebut diatas dapat dijelaskan sebagai berikut :

1) Persamaan regresi linear berganda tersebut menunjukkan nilai konstanta sebesar -220.681 dan bernilai negatif. Bilai tersebut berarti bahwa jika kedua variabel bebas (ROE dan DER) memiliki nilai 0 (nol) atau konstan, maka harga saham sebesar -220.681.

2) Koefisien regresi ROE sebesar 29.1 dan bernilai positif, maka menunjukkan adanya hubungan yang berbanding lurus terhadap harga saham. Jika nilai ROE bertambah satu satuan, maka harga saham akan naik sebesar 29.1 dengan asumsi variabel independen lainnya konstan. Nilai $r^{2}$ parsial variabel ROE sebesar 0.086 berarti bahwa variabel ROE hanya mampu menjelaskan variabel harga saham sebesar $8.6 \%$.

3) Koefisien regresi DER sebesar 677.962 dan bernilai positif, maka menunjukkan adanya hubungan yang searah terhadap harga saham. Jika terjadi penambahan pada nilai DER sebesar satu satuan, maka harga saham akan naik sebesar 677.962 dengan asumsi variabel independen lainnya adalah konstan. Nilai $r^{2}$ parsial untuk variabel DER sebesar 0.220 berarti bahwa variabel DER hanya mampu menjelaskan variabel harga saham sebesar $22 \%$.

Nilai koefisien determinasi berganda atau $R^{2}$ menunjukkan sejauh mana sumbangan pengaruh yang diberikan oleh variabel bebas terhadap variabel terikat. Apabila hasil uji $\mathrm{F}$ dalam analisis regresi nilainya signifikan atau lebih kecil dari 0.05 maka nilai koefisien determinasi berganda atau $R^{2}$ dapat digunakan untuk memprediksi seberapa besarnya kontribusi pengaruh variabel bebas terhadap variabel terikat. Nilai koefisien determinasi berganda atau $R^{2}$ menjadi tidak dapat digunakan untuk mengetahui pengaruh variabel bebas terhadap variabel terikat jika hasil uji $\mathrm{F}$ tidak signifikan atau lebih besar dari 0.05 . 
Koefisien korelasi atau $\mathrm{r}$ adalah suatu pengukuran statistik kovariasi atau asosiasi antara dua variabel. Nilai koefisien korelasi bernilai positif maka korelasi searah, begitu juga sebaliknya. Jika koefisien korelasi menunjukkan nilai $=1$ maka terjadi korelasi sempurna dengan kemiringan (slope) positif, dan jika nilai koefisien korelasi $=-1$ maka terjadi korelasi sempurna dengan kemiringan (slope) negatif. Nilai koefisien korelasi yang baik harus mendekti 1, semakin besar (mendekati 1) nilai R, maka semakin kuat korelasinya, begitu juga sebaliknya.

Hasil dari perhitungan SPSS diperoleh nilai $R^{2}$ sebesar 0.326 atau $32.6 \%$. Artinya, DER dan ROE hanya mempengaruhi harga saham sebesar $32.6 \%$ secara simultan, sisanya sebanyak $67.4 \%$ dipengaruhi oleh faktor lain diluar model yang diteliti. Sementara nilai koefisien korelasi atau $\mathrm{R}$ adalah sebesar 0.571. Nilai ini menunjukkan hubungan variabel DER dan ROE dengan variabel harga saham tidak terlalu kuat namun searah.

\section{E. SIMPULAN}

Berdasarkan hasil analisis data dalam penelitian tentang pengaruh return on equity dan debt to equity ratio terhadap harga saham perusahaan pulp \& paper yang tercatat di Bursa Efek Indonesia yang berlandaskan kepada kajian teori dan perumusan masalah, maka dapat disimpulkan beberapa hal berikut ini :

1. Analisis pengaruh kinerja keuangan yang diwakili dengan ROE terhadap harga saham pada perusahaan sub sektor pulp \& paper yang tercatat di BEI selama tahun 2012-2016 yaitu bahwa secara parsial variabel ROE tidak berpengaruh signifikan terhadap harga saham. Maka, hipotesis penelitian (H1) yang berbunyi bahwa ROE memiliki pengaruh yang berarti terhadap harga saham, ditolak.

2. Analisis pengaruh kinerja keuangan yang diwakili dengan DER terhadap harga saham pada perusahaan sub sektor pulp \& paper yang tercatat di BEI selama tahun 2012-2016 yaitu bahwa secara parsial variabel DER berpengaruh signifikan terhadap harga saham. Maka, hipotesis penelitian (H2) yang berbunyi bahwa DER memiliki pengaruh yang berarti terhadap harga saham, diterima.

3. Berdasarkan hasil uji regresi linear variabel ROE dan DER secara simultan (bersama-sama) memiliki pengaruh yang berarti terhadap harga saham perusahaan pulp \& paper yang tercatat di BEI pada tahun 2012-2016.

\section{DAFTAR PUSTAKA}

Aditya, R. Y. (2014). Pengaruh Kinerja Keuangan Terhadap Harga Saham Pada Perusahaan Rokok di Bursa Efek Indonesia. 21.

Agnes, S. (2005). Analisis Kinerja Keuangan dan Perencanaan Keuangan. Jakarta: PT. Gramedia.

Agus, S. (2008). Manajemen Keuangan Teori dan Aplikasi. Yogyakarta: BPFE. 
Brigham, F. E., \& Houston, J. (2010). Dasar-Dasar Manajemen Keuangan : Assetials of Financial Management . Jakarta: Salemba Empat.

Darmadji, T., \& Hendy, M. F. (2006). Pasar Modal di Indonesia Pendekatan Tanya Jawab. Jakarta: Salemba Empat.

Darsono, \& Ashari. (2010). Pedoman Praktis Memahami Laporan Keuangan (Tips Bagi Investor, Direksi, dan Pemegang Saham). Yogyakarta: Andi.

Erlina. (2008). Metodologi Penelitian Bisnis : Untuk Akuntansi dan Manajemen. Medan: USU Press.

Fahmi, I. (2012). Pengantar Pasar Modal. Bandung: Alfabeta.

Gere, M. F. (2015). Pengaruh Kinerja Keuangan Terhadap Harga Saham Perusahaan Manufaktur Di Bursa Efek Indonesia. Jurnal Ilmu dan Riset Manajemen Volume 4 Nomor 8, 17.

Ghozali, I. (2006). Aplikasi Analisis Multivariate dengan Program SPSS. Semarang: Badan Penerbit Universitas Diponegoro.

I. A. (2007). Standar Akuntansi Keuangan. Jakarta: Salemba Empat.

IAI. (2007). Standar Akuntansi Keuangan. Salemba Empat: Jakarta.

idx. (2012-2016). www.idx.co.id. Retrieved from www.idx.co.id.

Indriantoro, N., \& Supomo, B. (2002). Metodologi Penelitian Bisnis untuk Akuntansi dan Manajemen. Yogyakarta: BPFE.

Jogiyanto. (2008). Teori Portofolio dan Analisis Investasi. Yogyakarta: BPFE.

Notoadmodjo, S. (2010). Metodologi Penelitian Kesehatan. Jakarta: Rineka Cipta.

Panji, A., \& Pakarti, P. (2001). Pengantar Pasar Modal Edisi Revisi. Semarang: Rineka Cipta.

Putri, M. T. (2017). Pengaruh Profitabilitas dan Keputusan Investasi Terhadap Nilai Perusahaan Pulp \& Paper yang Terdaftar di Bursa Efek Indonesia. Jom FISIP Volume 4 No 2, 12.

Ramfineli, R. H., \& Ibrahim, M. (2016). Analisis Kinerja Keuangan dengan Rasio Profitabilitas dan Pengaruhnya Terhadap Harga Saham Perusahaan Sektor Industri Dasar dan Kimia Sub Sektor Pulp \& Paper di Bursa Ejek Indonesia. Jom FISIP Volume 3 No 2, 15. 
Satria, I., \& Hatta, I. H. (2015). Pengaruh Kinerja Keuangan Terhadao Harga Saham 10 Bank Terkemuka di Indonesia. Jurnal Akuntansi/Volume XIX, No. 02,18 .

Sugiyono. (2010). Metode Penelitian Pendidikan (Pendekatan Kuantitatif, Kualitatif, dan $R \& D)$. Bandung: Alfabeta.

Sugiyono. (2013). Metode Penelitian Bisnis. Bandung: Alfabeta.

Sugiyono. (2013). Metode Penelitian Bisnis. Bandung: Alfabeta.

Zuliarni, S. (2012). Pengaruh Kinerja Keuangan Terhadap Harga Saham Pada Perusahaan Mining dan Mining Service di Bursa Efek Indonesia (BEI). Jurnal Aplikasi Bisnis Vol 3 No 1, 13. 